\title{
Model of organizational processes developed within companies in order to innovate through technology transfer
}

\author{
Felicia Diana Nicoara ${ }^{1,2,}$, Andreea Maier ${ }^{1}$, Dorin Maier ${ }^{3}$ \\ ${ }^{1}$ Faculty of Mechanical Engineering, Technical University of Cluj-Napoca, Romania \\ ${ }^{2}$ The National Institute of Research and Development for Isotopic and Molecular Technologies, Cluj-Napoca, Romania \\ ${ }^{3}$ The Faculty of Economics, University of Economic Studies, Bucharest, Romania

\section{Email address:} \\ dannifeliss@gmail.com (F. D. Nicoara),maier_andreea@ymail.com (A. Maier), dorin.maier@gmail.com (D. Maier)
}

\section{To cite this article:}

Felicia Diana Nicoara, Andreea Maier, Dorin Maier. Model of Organizational Processes Developed Within Companies in Order to Innovate through Technology Transfer. International Journal of Economics, Finance and Management Sciences

Vol. 1, No. 4, 2013, pp. 196-204. doi: 10.11648/j.ijefm.20130104.13

\begin{abstract}
Innovation is known as the basic condition for the sustainability, durability and competitiveness of a business. A company's involvement in the technology transfer process together with a research organization that has an innovative scientific and technical outcome results is a real opportunity to innovate. For a successful innovation through technology transfer, the company should implement and carry out a number of specific organizational processes. As a result of a thorough literature review, this paper proposes a framework consisting of 17 processes, directly or indirectly subordinated to the innovation process through technology transfer. Based on their analysis, companies can establish their limits of competence and can allocate their resources effectively. Given that the company has a number of processes that cannot be implemented due to the lack of resources, managers may use the available resources of the partner research institution. Thus, the collaboration between the stakeholders participating in the technology transfer process is intended to result in an efficient use of available skills and resources, with a major influence on the outcome.
\end{abstract}

Keywords: Economic Development, Technology Transfer, Innovation, Research and Development, Organizational Processes

\section{Introduction}

In the economic and business environment, innovation is the catalyst for the development and the increasing competitiveness of organizations. In the organizational context, innovation is associated with positive changes regarding efficiency, productivity, quality, competitiveness and market position [1, 2]. Entrepreneurs have to constantly seek better ways to meet customer needs with products and services characterized by improved quality, attractive price and sustainability. This objective can be achieved through innovation and specific organizational strategies [3]. One of the most important sources of innovation for traders is technology transfer, the implementation of scientific results obtained by research organizations in production and consumption [4].

\section{Models of Innovation through Technology Transfer}

Technology transfer is a complex process implying an optimum and efficient collaboration between at least two organizations: the research organization that generates innovative results by carrying out scientific research and technological development activities, and the company that adopts and implements this result in order to improve products, processes or organizational environment. A third party often appears in this process, an intermediary facilitator.

From the company's perspective, organizational processes related to technology transfer play a crucial role as they must be subordinated to the ultimate goal pursued and integrated into the company's current organizational processes. For an effective exploitation of an innovative scientific result, the practice of countries with experience in 
this area has shown that a procedural approach, conducted step by step, ensures the effective management of the entire process, an overview of the final goal and a flexible, proactive approach, depending on the influence of the company's internal or external factors $[4,5]$.

Overall, the models present a merger and combination of different fields of competence of the organizations participating in the marketing process: research, product development, market research and marketing, business development and stresses the importance of the processes occurring before the creation process and the occurrence of innovative ideas. Many of these models consider the spin-off process when an entire business is developed based on an invention. Their analysis gives us an overview of the organizational processes unrolled during technology transfer within the company.

In his study, Mitasiunas, proposed a diagram (fig.1) which shows in an abstract way the technology transfer process developed by all organizations involved [6]. The company carries out processes in order to identify the need for technological innovation, establishing new technologies to be implemented and their effective implementation in production. If the process does not involve the organization acting as intermediary and support of technology transfer, the company, the research institution or both run processes in order to identify market needs, industrial applications that correspond to the innovation needs of the company, potential technology suppliers, contracting and other necessary support processes $[6,7]$.

Two of the most complex models of innovation within a company, using the spin-off process as a form of technology transfer, are those of Yenken and Gillin and the integrated model of De Cleyn and Braet $[4,7,8,9]$.

The model developed by Yenken and Gillin, (fig.2) shows the processes driven by spin-off technology transfer. There is an overall presentation of a series of processes that occur in the newly created company, starting with the establishment of the company's vision, business opportunities, technological development, laying out the business model and releasing the product on the market. The author emphasizes the importance of the entrepreneurial capacity of the company, which is significantly influenced by the company's activities, processes and infrastructure, as well as by the available resources and economic environment $[4,7,8,10]$.

The model developed by De Cleyn and Braet, (fig.3) is an integrated model where the processes related to technology transfer within the company are presented more explicitly. The processes are presented as follows: research processes, the feasibility of implementing innovative results, business plan development, product development and validation, implementation of business strategy, business plan development and adjustment $[4,6,9$,$] .$

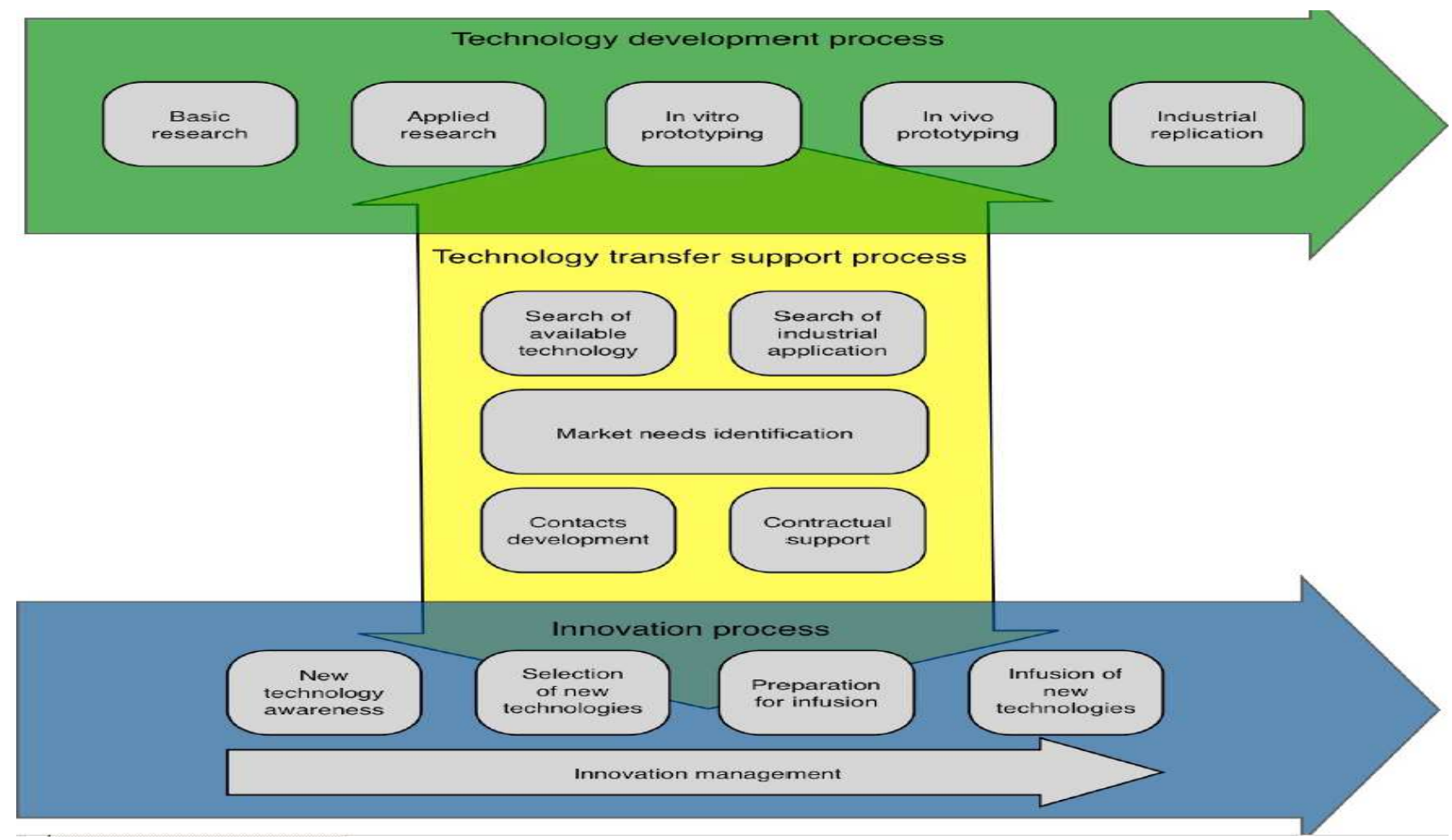

Figure 1. Technology transfer process diagram [6] 


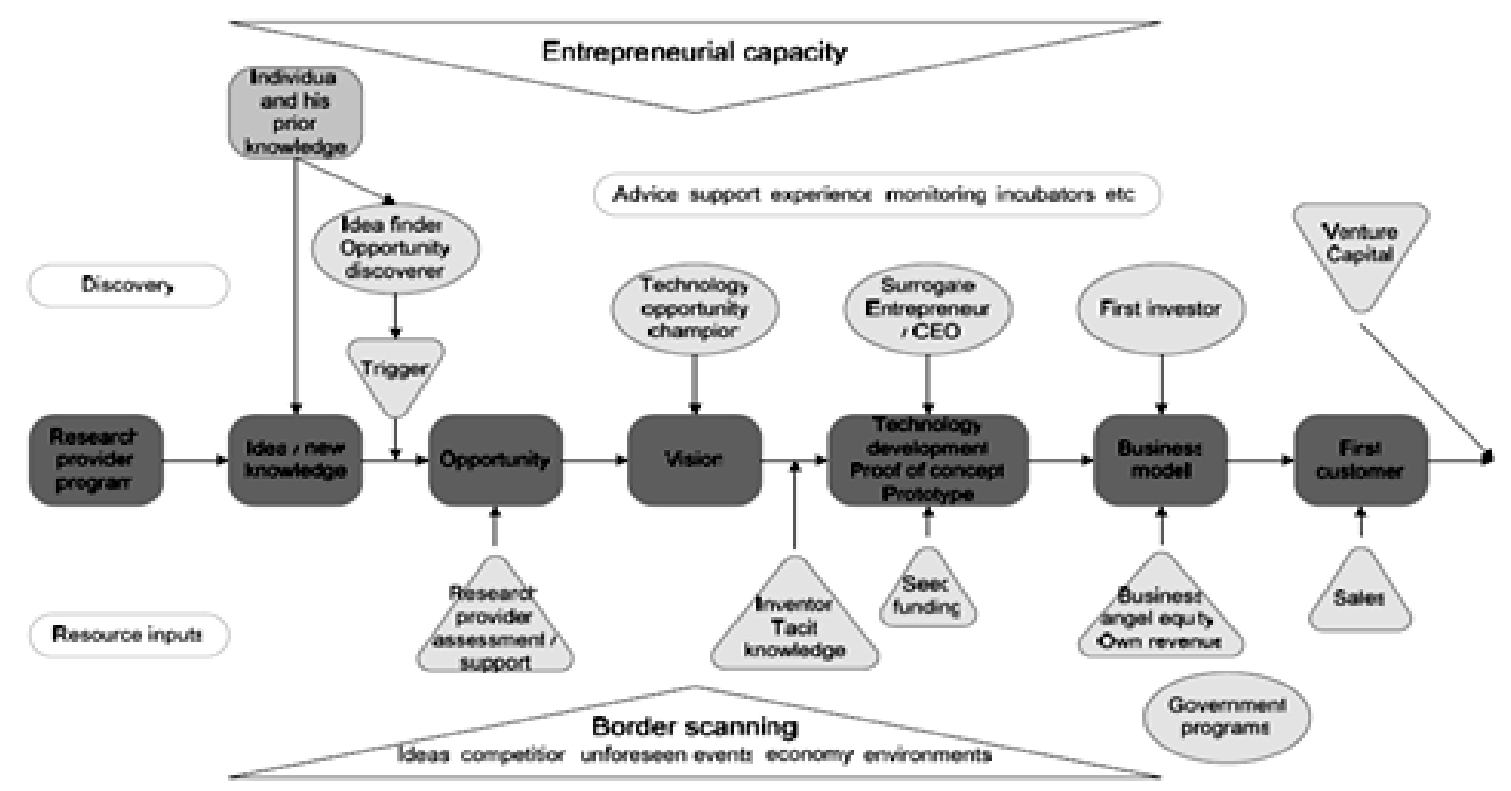

Figure 2. Development of spin-off companies [8]

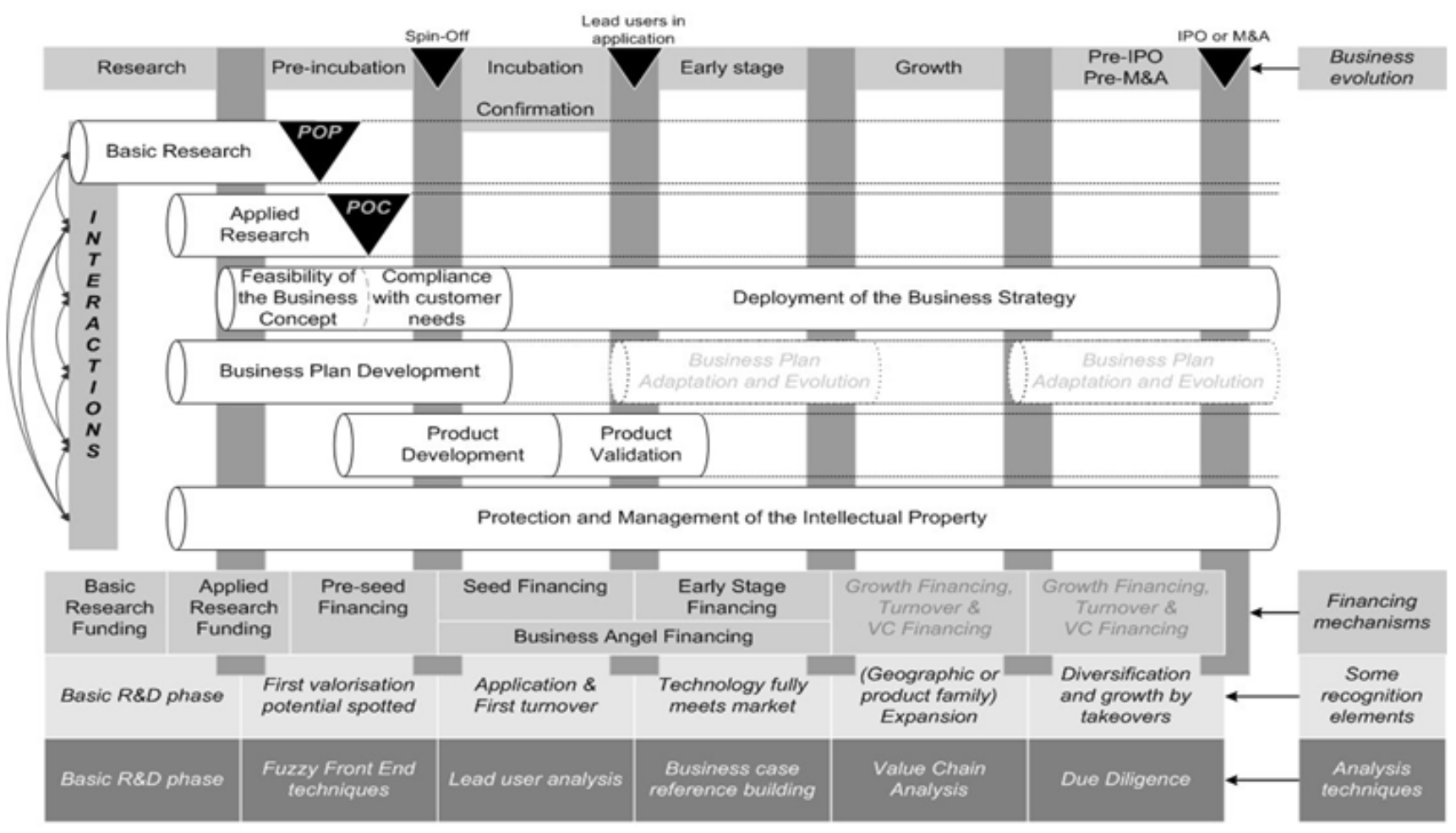

$P O P=$ Proof of Principle; $P O C=$ Proof of Concept; $I P O=$ initial Public Offering: MSA $=$ Merger and Acquisition; VC $=$ Venture Capital

Figure 3. Integrated model of the evolution of a spin-off process [9]

Other popular designs include Cooper's model, known as the "Stage-Gate" model, a model used to streamline the marketing of a new innovative product or the development of an existing one and to reduce the time required to launch it on the market [4, 11]. Jolly's model deals with the application of an invention or innovative technology in the economic sphere by splitting into two large sub-processes: basic processes, that lead to the exploitation of new media technologies, and processes designed to meet and engage the involved stakeholders in technology commercialization [4, 12]. The model developed by Rothwell and Yegfeld is a linear model that shows the relationship between all the 
components of the marketing trial and their interaction. The emphasis in this model is on the technological process, on marketing, and not necessarily on the business idea [4].

All these models (Table 1) have something in common, covering a wide range of processes occurring before the creative process, but there are differences in emphasis on certain key marketing elements.

Table 1. Key processes in the commercialization of research results [12]

\begin{tabular}{|c|c|c|}
\hline Cooper's model (1986) & Jolly's model (1997) & Rothwell and Yegfeld's model (1995) \\
\hline Discover innovative scientific ideas & $\begin{array}{l}\text { Generate new business concepts or product innovation by } \\
\text { identifying the needs of the company through technology } \\
\text { and market analysis }\end{array}$ & Generate innovative ideas \\
\hline $\begin{array}{l}\text { Preliminary evaluation of innovation } \\
\text { projects }\end{array}$ & $\begin{array}{l}\text { Establishment of technological options and preparing the } \\
\text { product for production }\end{array}$ & Research and development \\
\hline $\begin{array}{l}\text { Create business ideas by thorough } \\
\text { technology and market assessment }\end{array}$ & $\begin{array}{l}\text { Product development, prepare it for the market, testing, } \\
\text { prototype validation, feasibility testing }\end{array}$ & Prototype production \\
\hline $\begin{array}{l}\text { Prototype development and new product } \\
\text { design }\end{array}$ & $\begin{array}{l}\text { Promote the product in order to be accepted on the } \\
\text { market }\end{array}$ & Production \\
\hline Prototype testing and validation & Extend the product's life cycle & Marketing \\
\hline Product launch on the market & & Market support \\
\hline Product assessment after launching & & \\
\hline
\end{tabular}

Goldsmith's strategy is an action plan for effective marketing of innovative technologies (Table 2). The marketing process is divided into 3 major phases, 6 rounds, 18 steps and a multitude of activities necessary for successful sales [4].

Table 2. Goldsmith's model for commercialization of innovative technologies [4]

\begin{tabular}{|c|c|c|c|}
\hline & Technology & Market & Business \\
\hline \multicolumn{4}{|c|}{ The Conceptual Phase } \\
\hline $\begin{array}{c}\text { Stage 1 } \\
\text { Investigation }\end{array}$ & $\begin{array}{l}\text { Technical } \\
\text { analysis }\end{array}$ & $\begin{array}{c}\text { Studies } \\
\text { regarding } \\
\text { market needs }\end{array}$ & $\begin{array}{c}\text { Business idea } \\
\text { evaluation }\end{array}$ \\
\hline \multicolumn{4}{|c|}{ The Application Phase } \\
\hline $\begin{array}{c}\text { Stage } 2 \\
\text { Feasibility }\end{array}$ & $\begin{array}{l}\text { Technical } \\
\text { feasibility }\end{array}$ & Market study & $\begin{array}{l}\text { Economic } \\
\text { feasibility }\end{array}$ \\
\hline $\begin{array}{c}\text { Stage } 3 \\
\text { Development }\end{array}$ & $\begin{array}{c}\text { Prototype } \\
\text { design }\end{array}$ & $\begin{array}{c}\text { Strategic } \\
\text { marketing plan }\end{array}$ & Business plan \\
\hline $\begin{array}{c}\text { Stage } 4 \\
\text { Launching }\end{array}$ & $\begin{array}{l}\text { Prepare for } \\
\text { launching }\end{array}$ & $\begin{array}{l}\text { Prototype } \\
\text { conception }\end{array}$ & $\begin{array}{c}\text { Market } \\
\text { evaluation }\end{array}$ \\
\hline \multicolumn{4}{|c|}{ The Development Phase } \\
\hline $\begin{array}{c}\text { Stage } 5 \\
\text { Development }\end{array}$ & Production & $\begin{array}{l}\text { Marketing and } \\
\text { distribution }\end{array}$ & $\begin{array}{c}\text { Business } \\
\text { development }\end{array}$ \\
\hline $\begin{array}{l}\text { Stage } 6 \\
\text { Maturity }\end{array}$ & $\begin{array}{l}\text { Providing } \\
\text { support to } \\
\text { maintain } \\
\text { production }\end{array}$ & $\begin{array}{c}\text { Market } \\
\text { diversification }\end{array}$ & $\begin{array}{l}\text { Business } \\
\text { maturity }\end{array}$ \\
\hline
\end{tabular}

This model is one of the most popular linear models found in the literature, being structured as a checklist for the processes required for a new technology within a company. The model has a number of sequential steps to be followed in a specific order. The process cannot move forward from one stage or from one phase to another until the technological, market and business management issues have been solved. The model is designed to assist those involved in the marketing of this technology, in assessing progress, in identifying technical and informational needs and in assessing costs and estimating the financial resources required [4].

In a study conducted by Henard and Szymanski, on the success of the innovation process, after analyzing a total number of 60 empirical studies in the literature, they identified 24 issues that directly influence the innovation process within a company. These issues have been classified into four categories: (1) product characteristics (price, degree of novelty, degree of customer satisfaction), (2) the characteristics of the company's strategy (the ability of the company to create a competitive advantage), (3) the characteristics of business processes, and (4) market characteristics. Of the 24 issues, 11 were found as subordinated to the company's processes, 5 to the company's strategy, 5 to product characteristics, and 3 to market characteristics. This study emphasizes that the company's internal processes play a significant role in the success of the innovation process. Internal processes include aspects of interaction between company departments, levels of competence of firms, company management, market orientation, development, marketing and launching of new products $[4,13]$.

\section{Framework Model of Company Specific Organizational Processes, Developed for Innovation through Technology Transfer}

Innovation is not only about the existence of an innovative idea, it involves substantial and systematic efforts of creativity, initiative and effective and rapid solutions for the implementation of innovative ideas within a company. Organizational innovation is directly influenced by four elements (Fig.4): resources, infrastructure, organizational culture and organizational processes. There 
must be a perfect balance between these elements [14].

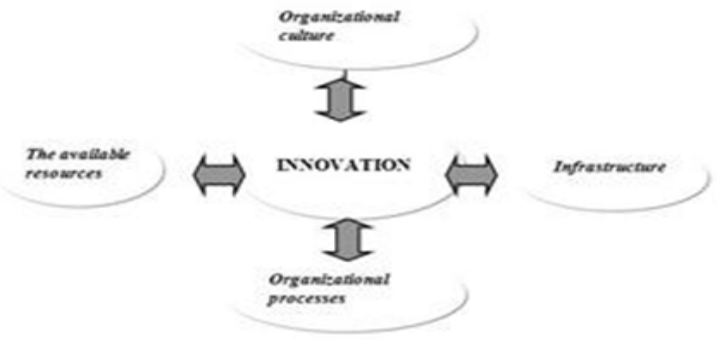

The current practice for innovation implementation through technology transfer within a company highlights the need for effective ongoing basic organizational processes and innovation support processes.

Looking at some of the most relevant models in the literature, we created a framework that includes several basic and support processes absolutely necessary for the optimal evolution of the technology transfer process within a company. Thus, we identified 17 basic and support processes for innovation through technology transfer (Table 3) .

Figure. 4. Elements influencing innovation [14]

Table 3. Organizational processes within companies required for innovation through technology transfer

\begin{tabular}{|c|c|c|c|}
\hline No. & $\begin{array}{l}\text { Organizational processes within } \\
\text { companies required for innovation } \\
\text { through technology transfer }\end{array}$ & Specific activities & $\begin{array}{l}\text { Process } \\
\text { type }\end{array}$ \\
\hline P1 & $\begin{array}{l}\text { Analyzing the organization's need for } \\
\text { innovation in order to carry out the } \\
\text { company's strategic business plan }\end{array}$ & $\begin{array}{l}\text { Management analysis; Analysis of the existing production methods and } \\
\text { technologies; Economic / financial analysis; Product portfolio / market services } \\
\text { analysis; Assessment of business development ideas and the increase of } \\
\text { competitive advantage from various sources (employees, external environment, } \\
\text { customers); }\end{array}$ & Support \\
\hline P2 & $\begin{array}{l}\text { Establishing the company's technology } \\
\text { strategy as part of the organization's } \\
\text { strategy to meet the business plan }\end{array}$ & $\begin{array}{l}\text { Establishing a strategic plan in order to update and develop the existing } \\
\text { technologies and working methods within the company; } \\
\text { Establishing a strategic plan to introduce the new methods or technologies in the } \\
\text { production flow; } \\
\text { Establish an organizational structure and the resources allocated for the short, } \\
\text { medium and long term implementation of the technology plan; }\end{array}$ & Support \\
\hline P3 & $\begin{array}{l}\text { Conducting research and development } \\
\text { activity according to the established } \\
\text { strategy }\end{array}$ & $\begin{array}{l}\text { Fundamental research (validation of theories and concepts); Applied research } \\
\text { (development of technologies / products, prototypes, etc. with practical } \\
\text { application); }\end{array}$ & Support \\
\hline P4 & $\begin{array}{l}\text { Evaluating the internal technical capacity } \\
\text { required for the implementation of the } \\
\text { technology plan of development, } \\
\text { modernization or introduction of new } \\
\text { technologies in the production process }\end{array}$ & $\begin{array}{l}\text { Identifying existing technologies that can be upgraded or adapted; Identifying } \\
\text { the new technological variants desired to be implemented; Identifying the } \\
\text { required basic and support technologies; Assessing the internal capacity needed } \\
\text { in order to achieve and implement the desired innovation; Identifying the } \\
\text { optimum methods to implement innovation (technology transfer, internal } \\
\text { research activity, services that require outsourcing, etc.); }\end{array}$ & Basic \\
\hline P5 & $\begin{array}{l}\text { Making connections with the research } \\
\text { environment (institutes, universities, } \\
\text { research centers) }\end{array}$ & $\begin{array}{l}\text { Constant interaction with research institutes which can provide innovation } \\
\text { through their specific activity; }\end{array}$ & Support \\
\hline P6 & $\begin{array}{l}\text { Choosing the technology provider } \\
\text { (NIRD), which has the necessary } \\
\text { technology to meet the need for innovation }\end{array}$ & $\begin{array}{l}\text { Market Research on R\&D organizations that may be potential suppliers of } \\
\text { innovative products / technology; Discussions, visits, tests, etc. to identify the } \\
\text { R\&D organization with the necessary technology or with the resources required } \\
\text { to create it; }\end{array}$ & Basic \\
\hline P7 & $\begin{array}{l}\text { Technical evaluation of the innovation } \\
\text { desired to be implemented }\end{array}$ & $\begin{array}{l}\text { Feasibility study evaluating the technological innovation (idea) with potential for } \\
\text { implementation; Technology plan preparation and analysis (technical documents, } \\
\text { plans, drawings); Prototype development / acquisition / testing, if possible; } \\
\text { Identifying support technologies (derived); Identifying key issues of technology } \\
\text { and finding more possible solutions; } \\
\text { Establishing an implementation strategy; } \\
\text { Analyzing possible variants regarding the result / cost ratio; } \\
\text { Identifying the main technological aspects regarding the possible future } \\
\text { development and modernization by providing further research and consulting } \\
\text { services; }\end{array}$ & Basic \\
\hline
\end{tabular}




\begin{tabular}{|c|c|c|c|}
\hline No. & $\begin{array}{l}\text { Organizational processes within } \\
\text { companies required for innovation } \\
\text { through technology transfer }\end{array}$ & Specific activities & $\begin{array}{l}\text { Process } \\
\text { type }\end{array}$ \\
\hline $\mathbf{P 8}$ & $\begin{array}{l}\text { Assessing the impact of technological } \\
\text { innovation on business activity, } \\
\text { customers, environment and society }\end{array}$ & $\begin{array}{l}\text { Evaluating the impact of technology on business; } \\
\text { Estimating economic and trade impact; } \\
\text { Estimating environmental impact; } \\
\text { Estimating social impact; }\end{array}$ & Basic \\
\hline P9 & IPR Protection & $\begin{array}{l}\text { Preparing the documentation for patenting or other intellectual property rights } \\
\text { protection; }\end{array}$ & Basic \\
\hline P10 & $\begin{array}{l}\text { Preparing a business plan, operational, } \\
\text { entrepreneurial and financial plan }\end{array}$ & $\begin{array}{l}\text { Substantiating some financial and economic instruments and decision making } \\
\text { management instruments; }\end{array}$ & Basic \\
\hline P11 & $\begin{array}{l}\text { Technology plan negotiation and } \\
\text { implementation by means of TT }\end{array}$ & $\begin{array}{l}\text { Establishing the strategy and the implementation plan; } \\
\text { Establishing scenarios based on the identified risks; } \\
\text { Establishing the resources and skills allocated by the provider and by the } \\
\text { beneficiary; } \\
\text { Setting location and ensuring advisory services and technical support; } \\
\text { Establishing a project team, an organizational hierarchy, the document flow, the } \\
\text { document format; } \\
\text { Identifying the scope of the agreement (products and services, tangible and } \\
\text { intangible goods); } \\
\text { Establishing service and post-warranty services; } \\
\text { Contract pricing and payment method; } \\
\text { Establishing a procedure in order to solve conflicts; } \\
\text { Determining the accepted degree of risk / failure; } \\
\text { Establishing penalties fin case of non-compliance with contract requirements; } \\
\text { Establishing the management of unexpected additional changes; } \\
\text { Safeguarding quality assurance; }\end{array}$ & Basic \\
\hline P12 & Conducting TT activities & Technology integration and implementation in production; & Basic \\
\hline P13 & $\begin{array}{l}\text { Control, monitoring and periodic } \\
\text { evaluation of results }\end{array}$ & $\begin{array}{l}\text { Elaborating performance and result indicators necessary for the evaluation of the } \\
\text { success of the TT process; }\end{array}$ & Basic \\
\hline P14 & Necessary changes and adjustments & $\begin{array}{l}\text { Establishing work procedures in case of technical / technological and process } \\
\text { changes to the original plan; } \\
\text { Recalculating and updating budgets for some changes to the original plan; }\end{array}$ & Basic \\
\hline P15 & $\begin{array}{l}\text { Conducting post-implementation service } \\
\text { activities }\end{array}$ & Establishing a plan for post-implementation checks and adjustments; & Support \\
\hline P16 & $\begin{array}{l}\text { Upgrading and rehabilitating technology } \\
\text { depending on the business plan and the } \\
\text { activity of the company }\end{array}$ & $\begin{array}{l}\text { Identifying and developing technical proposals of technological efficiency / } \\
\text { modernization; }\end{array}$ & Support \\
\hline P17 & $\begin{array}{l}\text { Establishing the financial plan for } \\
\text { business/technology development }\end{array}$ & Identifying different sources of financing and the access to them; & Support \\
\hline
\end{tabular}

These basic and support processes performed for the emergence of the innovation phenomenon and for the support of the production transfer of an innovative scientific result require specific allocation of power and specific resources needed for their effective and efficient operation. In order to assess the final results of the technology transfer process, it is necessary to set and pursue certain success factors.

\section{The Role and Importance of Specific Processes Related to Technology Transfer within the Company}

For companies producing goods and services, one of the major attempts in the organizational implementation of basic 
and support processes for an effective technology transfer process is the need to create a connection between these processes and the business strategy and to obtain the desired results on medium and long term. The implementation of these processes must be carried out with the support and contribution of all staff because their operation has a major impact on business results. Most companies fail when it comes to innovation because they cannot adapt fast enough to the changes required by the market due to organizational processes, procedures, internal systems and structure acting as barriers to efficient activity and decision-making processes.

Identifying and analyzing the organization's requirements for innovation in order to carry out the strategic business plan is a basic process in securing market position and a favorable level of competitiveness. The need for innovation is identified through a permanent analysis of the economic and financial evolution of the business. It is necessary to analyze product portfolio, product quality, labor productivity, technological characteristics of the equipment, methods, manufacturing processes and recipes used. Another important aspect is the evaluation of certain innovative ideas, triggering business development and increasing competitive advantage derived from various sources: employees, external environment, customers [12].

Establishing and implementing the company's technology strategy as part of the organization's strategy in order to meet the business plan consists in identifying, developing and implementing those technological skills that provide the company with a competitive advantage. Establishing $a$ technology strategy means setting a strategic plan for the modernization and development of technologies or working methods within the company, establishing a strategic plan to introduce the new methods or technologies in the production flow and establishing the strategy for acquiring the technologies required in order to implement the innovation plan. Technology strategy must be integrated into the company's business strategy $[10,15]$.

Technology strategy is set based on efficient technology management. Technology management involves the company's effective management of all key processes: applied research, technology development, planning, engineering, mechanics, software, production and communication. To support technology strategy, the firm must conduct various studies and assessments on its evolution in terms of production technology. Thus, it is also necessary to develop relationships with other companies within the same department, with research institutes and universities, as they are the leading providers of innovative technological ideas [16].

The evaluation of the internal technical capacity required for the implementation of the technology plan of development, modernization and introduction of new technologies in the production process is a necessary step in substantiating the decision on how to obtain the necessary technology. This process consists of activities assessing and identifying existing technologies that can be upgraded or developed. The desired innovative technological options to be implemented and the necessary supporting technologies are being identified. The internal capacities to achieve and implement the desired innovation are assessed and the optimal variants for the implementation of innovation are being identified (technology transfer, internal research, services which requires outsourcing, etc.) $[5,10]$.

Technology transfer process is therefore initiated as a result of the company's decision to acquire the necessary technology from a research organization that owns an innovative result corresponding to its needs. Small and medium businesses find it difficult to have their own internal research and development department and the use of organizations that provide technology is the best solution. The company must go through a series of phases when deciding to purchase new technology or to develop the existing one by collaborating with another external organization $[12,17]$.

After identifying the need for innovation and deciding to purchase it through technology transfer process, the necessary technology and the subject of technology transfer must be established. In this regard, the company must conduct a technical assessment of the technology and analyze the issues related to innovative technology in order to achieve superior performance in terms of costs and quality regarding the final product. Another aspect that the company must consider is whether the necessary technology is compatible with the existing technology, or is intended to fill in, because in this case it is important that technology is purchased from an organization that already owns it, in order to shorten time and decrease costs for its introducing in production. To ensure the successful market launch of an innovative product, the company must be able to define its available capabilities and resources, to assess them and to identify those resources that are missing but which are required for the success of the business [18].

Because there is a significant impact of new technology on the business activity, it is necessary to develop a set of economic, financial and entrepreneurial instruments, such as a business plan, an operational plan, an entrepreneurial plan and a financial plan, in order to support the technology transfer process. Developing a business plan calls for more interdisciplinary interactions and functional collaboration between company departments or between the company and another organization [19, 20].

Developing a network of contacts with the research environment, represented by organizations such as research institutes, research centers in universities or private research centers, is a basic premise in finding a favorable method of purchasing the necessary technology. There are various ways of collaborating with research organizations, depending on technology characteristics. The technology transfer process consists of three critical points of interest: the idea, the prototype and the final product [21].

The collaboration with research organizations can provide the scientific and technical support necessary to ensure the transition from idea to prototype and then, the final product 
that will be marketed. The final selection of technologies to be acquired and the technology provider is the last stage before formal negotiations and before establishing the implementation strategy of innovation in production. In this phase, all the proposals regarding technical variants, the necessary technological components, the capabilities and skills to be insured, the features and performance of the technology provider are all being evaluated.

Negotiation and implementation strategy assessment is a critical phase in the technology transfer process. One of the most problematic aspects of negotiation is the assessment of the value of the technology which will be transferred and its support services. The bargaining power of an institute that transfers scientific research results can lie in the quality of the resources that it holds, including the technology desired by the entrepreneur, market research reputation, the performance of the management system, capital and connections with the economic and scientific environment. The bargaining power of the company usually lies in its knowledge in terms of production, local and regional market, local and regional market access, low cost of labor and political connections $[4,10,18]$.

The phase of establishing an implementation project requires the company to: identify changes in the organizational structure determined by the implementation of innovative ideas in production, identify changes to be made in the internal knowledge management system and in policies in order to adjust to the change, develop training and retraining programs for the personnel involved in production processes where changes will take place, establish evaluation criteria and a realistic implementation plan $[4,7,10,18]$.

Substantiation of a technology modernization and rehabilitation plan in response to market changes is necessary for the decision of whether to continue using the existing technology or focus on acquiring new technology. A successful technology transfer project can lead to a long and stable partnership between the supplier and the technology implementer, paving the way for other collaborative projects $[4,10]$.

\section{Conclusions}

To stay competitive, organizations need to innovate, but in a changing market, the initiation and planning process of innovation through technology transfer is difficult and challenging. The company's efforts to implement an innovative scientific result should be oriented towards the strategic objectives that are to be achieved and must be communicated within the organization based on a hierarchical structure. It is very important to know any prior research and technological development existing in the same field or in a complementary or similar field, accomplished according to the specific requirements of a particular market. All stakeholders involved in the implementation of innovation should be identified and an effective communication and collaboration must be established so that resources can be allocated effectively and efficiently.

All departments within the organization must be assessed in order to use their expertise for innovation, as this is a company-wide effort. If necessary, organizations must employ new people to provide specialized skills needed for innovation. An organization that runs an innovation process must have the support of the top management whose involvement must be active and permanent. To achieve the expected results, success criteria and success indicators must be clearly defined. Setting a realistic time frame for implementation, which is mutually accepted by the implementation team, is also very important when it comes to dynamic market prices and costs of innovation. Identifying and using the management and operational tools as well as the correct choice of processes required to drive innovation, are key factors influencing the outcome.

The proposed model can be used by companies as a checklist regarding the existing basic and support processes subordinated to the technology transfer process, absolutely necessary to be undertaken in order to be effective.

Analyzing the processes of the proposed model in parallel with the processes conducted by a research organization regarding technology transfer may provide important information on the effectiveness of this approach and can be the base of future studies. The lack of a process or its inefficient performance may result in technology transfer failure.

\section{Acknowledgements}

This paper benefited from financial support through the "Increasing the quality of doctoral studies in engineering sciences to support the development of knowledge based society" project, POSDRU/107/1.5/s/78534, a project cofounded by the European Social Fund through the sectoral operational program of human resources development 2007-2013.

\section{References}

[1] T.O., Salge, A Vera,. (2009), Hospital innovativeness and organizational performance, Health Care Management Review, Vol. 34, Issue 1, pp. 54-67.

[2] ***, (2013), Sensgent Dictionary. Definition of innovation. Available on-line http://dictionary.sensagent.com/innovation/en-en/

[3] P., Heyne, P. J., Boettke, D. L., Prychitko, (2010), The Economic Way of Thinking. Prentice Hall, 12th ed. Pp. 163, 317-318.

[4] G., Ferguson, (2008), Commercialisation Models. Unpublished. Available online at http://www.rumourcontrol.com.au/analysis/commercialisatio n_models.pdf;

[5] G., Banusanu, F., Ionita, D., Savin, (2008), Theoretical and Applied Economics, The influence of the conjunctural factors toward the reengineering of organization. Vol. $10, \mathrm{pp}$ 
$61-70$.

[6] Mitasiunas J., 2012, Innovation and Technology Transfer, BONITA project, available on line at http://www.bonita-project.eu/cms_uploads/files/a02innovati ontech.pdf

[7] ***, (2013), Wikipedia, COREUS, White Paper, Improving the Execution of Strategy. Available at $\mathrm{http}: / /$ www.corpeum.com/assets/pdf/Improving the executi on_of_strategy.pdf

[8] J., Yencken, M., Gillin, 2002, Survey of University Spin-off Companies, Australia. Research Paper. Australian Graduate School of Entrepreneurship, Swinburne University of Technology, Australia.

[9] S., De Cleyn, J., Braet (2006), The evolution and performance of spin-off ventures: integration and elaboration of existing models, University of Antwerp, Belgium.

[10] NIST, (2013), National Institute of Standards and Technology. A toolkit for Evaluating Public R\&D Investments. Unpublished.

[11] R. C., Cooper, E. J., Kleinschmidt (1988), Resource Allocation in the New Product Process. Industrial Marketing Management, vol. 17, pg. 249-262.

[12] APCTT, Asian and Pacific Centre for Transfer of Technology, (2012), Tehnology Handbook, Available on line at. http://www.technology4sme.net/tech_handbook.aspx.

[13] D., H., Hernard, D., M., Szymanski, (2001), Why some new product are more successful than Others. Journal of Marketing Research, vol 38, pg. 362-375.

[14] S., Brad, C., Ciupan L., Pop B., Mocan, M., Fulea (2006),
Basic manual of product manager and engineering innovation management. Editura Economică, Bucureşti 2006.

[15] N., Maheran, M., C., Jantan Keong 2008, Technology Strategy and Firm Revenue Growth: Empirical Evidence of Malaysian Industrial Automation Industry, International Journal of Bussines and Management, Vol 3, Nr.7.

[16] K., H., Vehkapera., H., Haapasalo, J., P., Rusanen, (2009), Analyisis of Technology Management Functions in Finnish High Tech Companies. The Open Management Journal, vol 2, pg. 1-10.

[17] R., Sampson (2007), R\&D Alliances and Firm Performance:the Impact of Technological Diversity and Alliance Organization on Innovation, Academy of Management Journal, Vol 50, No 2.

[18] K., Ramanathan, (2012) An overview of Technology Transfer and Technology Transfer Models. Availeble on line at http://www.businessasia.net/Pdf_Pages/Guidebook

[19] A., Krattinger, L., Mahoney, L., Nelsen, J., A., Thomson A., B., Bennett, K., Satyanarayana, G., D., Graff, C., Fernandez, S., P., Kowalski, (2007), Executive guide to Intelectual Property Management in Health and Agricultural Innovation: A Handbook of Best Practices. Disponibil on-line la www.ipHandbook.org.

[20] A., L., Strenc (2011), Evaluation of the results of research and development R \& D innovation intellectual property rights resulting from these activities for technology transfer. Romanian Journal of Industrial Property, nr. 1/2011.

[21] E.M., Rogers (1995), The role of the research university in the spin-off of high technology companies, Technovation, no.4, pg 169-181. 